\title{
Meningkatkan Prestasi Belajar IPS Materi Mengenal Perkembangan Tehnologi Transportasi Dengan Mode Lctl (Contecxtualteaching And Learning) Siswa Kelas IV Semester II SDN 2 Lekor Kecamatan Janapria Tahun Pelajaran 2016/2017
}

\author{
Siti hajar \\ SDN 2 Lekor Kecamatan Janapria
}

\begin{abstract}
Abstrak. Untuk membangkitkan semangat belajar maka dalam pelajaran IPS harus memilih metode yang tepat. Metode yang di pilih dalam pembelajaran harus metode dengan pendekatan yang berpusat pada siswa sehingga siswa merasa lebih terdorong untuk turut aktif dalam pembelajaran. Pendekatan CTL(Contextual Teaching and Learning) merupakan pendekatan dengan konsep dasar yang mewadahi, menginspirasi, menguatkan, dan melatari pemikiran tentang bagaimana metode pembelajaran diterapkan berdasarkan teori tertentu. Pada materi Mengenal perkembangan Tehnologi Tramsportasi yang di ajarkan di Kelas IV Sekolah Dasar Negeri 2 Lekor Kecamatan Janapria pendekatan CTL(Contextual Teaching and Learning) di rasa tepat sehingga akan di gunakan dalam penelitian ini sebagai cara untuk meningkatkan prestasi belajar siswa pada materi Mengenal perkembangan Tehnologi Tramsportasi . Permasalahan yang di angkat dalam PTK ini adalah Meningkatkan Semangat Belajar Siswa Dalam Pembelajaran Mengenal perkembangan Tehnologi Tramsportasi Melalui Pendekatan CTL(Contextual Teaching and Learning) di Kelas IV Semester II Sekolah Dasar Negeri 2 Lekor Kecamatan Janapria Tahun Ajaran 2016/2017. Hasil akhir dari penelitian ini adalah Dengan Pendekatan CTL(Contextual Teaching and Learning) yang telah dilaksanakan maka terdapat peningkatan Semangat Belajar Siswa Dalam Pembelajaran Mengenal perkembangan Tehnologi Tramsportasi pada siswa Kelas IV Sekolah Dasar Negeri 2 Lekor Kecamatan Janapria . Terbukti dari data hasil belajar pada siklus 1 nilai rata rata yang siswa mencapai 72,1 Dan hasil rata rata nilai siswa yang pada siklus 2 ini mencapai 77,5. Dapat di simpulkan bahwa penggunaan Pendekatan CTL(Contextual Teaching and Learning) dalam meningkatkan Prestasi Belajar Siswa Dalam Pembelajaran IPS materi Mengenal perkembangan Tehnologi Tramsportasi.
\end{abstract}

Kata Kunci : Prestasi Belajar "Mengenal perkembangan Tehnologi Tramsportasi , Pendekatan CTL(Contextual Teaching and Learning)

\section{PENDAHULUAN}

\section{Latar Belakang Masalah}

Kelangsungan dan keberhasilan proses belajar mengajar bukan hanya dipengaruhi oleh faktor intelektual saja, melainkan juga oleh faktorfaktor nonintelektual lain yang tidak kalah penting dalam menentukan hasil belajar seseorang, salah satunya adalah kemampuan seseorang siswa untuk meprestasi dirinya. Mengutip pendapat Daniel Goleman (2004: 44), kecerdasan intelektual (IQ) hanya menyumbang $20 \%$ bagi kesuksesan, sedangkan $80 \%$ adalah sumbangan faktor kekuatan-kekuatan lain, diantaranya adalah kecerdasan emosional atau Emotional Quotient (EQ) yakni kemampuan meprestasi diri sendiri, mengatasi frustasi, mengontrol desakan hati, mengatur suasana hati (mood), berempati serta kemampuan bekerja sama.

Semangat belajar sangat penting artinya dalam kegiatan belajar, sebab adanya semangat mendorong siswa meningkatkan prestasi belajar dan sebaliknya kurang adanya semangat akan melemahkan prestasi belajar. Semangat merupakan syarat mutlak dalam belajar; seorang siswa yang belajar tanpa semangat (atau kurang prestasi) tidak akan berhasil dengan maksimal.

Dalam implikasinya pada dunia belajar, siswa atau pelajar tidak akan terprestasi secara penuh dalam belajar. Termasuk dalam mata pelajaran IPS yang di rasa membosankan. Guru sebagai seorang pendidik harus tahu apa yang diinginkan oleh para siswanya. Seperti kebutuhan untuk berprestasi, karena setiap siswa memiliki kebutuhan untuk berprestasi yang berbeda satu sama lainnya. Tidak sedikit siswa yang memiliki semangat belajar yang rendah, mereka cenderung takut gagal dan tidak mau menanggung resiko dalam mencapai prestasi belajar yang tinggi. Meskipun banyak juga siswa yang memiliki semangat belajar yang tinggi. Siswa memiliki semangat belajar tinggi kalau keinginan untuk sukses benar-benar berasal dari dalam diri sendiri. Siswa akan bekerja keras baik dalam diri sendiri maupun dalam bersaing dengan siswa lain.

Untuk membangkitkan semangat tersebut, maka dalam pelajaran IPS harus memilih metode yang tepat. Metode yang di pilih dalam pembelajaran harus metode dengan pendekatan yang berpusat pada siswa sehingga siswa merasa 
lebih terdorong untuk turut aktif dalam pembelajaran.

Pendekatan CTL(Contextual Teaching and Learning) merupakan pendekatan dengan konsep dasar yang mewadahi, menginspirasi, menguatkan, dan melatari pemikiran tentang bagaimana metode pembelajaran diterapkan berdasarkan teori tertentu.

Pada materi Mengenal perkembangan Tehnologi Tramsportasi yang di ajarkan di Kelas IV Sekolah Dasar Negeri 2 Lekor Kecamatan Janapria pendekatan CTL(Contextual Teaching and Learning) di rasa tepat sehingga akan di gunakan dalam penelitian ini sebagai cara untuk meningkatkan prestasi belajar siswa pada materi Mengenal perkembangan Tehnologi Tramsportasi

Semangat dalam pengertian yang berkembang di masyarakat sering-kali disamakan dengan prestasi. Oleh karena itu untuk dapat memahami dan mempunyai gambaran yang luas, berikut ini diberikan

beberapa pengertian prestasi antara

lain

Wlodkowski (dalam Suciati, 2001:52) menjelaskan prestasi sebagai suatu kondisi yang menyebabkan atau menimbulkan perilaku tertentu, serta yang memberi arah dan ketahanan (persistence) pada tingkah laku tersebut.

Pendekatan adalah konsep dasar yang mewadahi, menginspirasi, menguatkan, dan melatari pemikiran tentang bagaimana metode pembelajaran diterapkan berdasarkan teori tertentu. Oleh karena itu banyak pandangan yang menyatakan bahwa pendekatan sama artinya dengan metode. Pendekatan ilmiah berarti konsep dasar yang menginspirasi atau melatarbelakangi perumusan metode mengajar dengan menerapkan karakteristik yang ilmiah. Pendekatan pembelajaran ilmiah (CTL(Contextual Teaching and Learning) teaching) merupakan bagian dari pendekatan pedagogis pada pelaksanaan pembelajaran dalam kelas yang melandasi penerapan metode ilmiah. Penerapan pendekatan saintifik dalam pembelajaran harus memenuhi tiga prinsip utama, yaitu: 1) Belajar siswa aktif, dalam hal ini termasuk inquiry-based learning atau belajar berbasis penelitian, cooperative learning atau belajar berkelompok, dan belajar berpusat pada siswa, 2) Assessment berarti pengukuran kemajuan belajar siswa yang dibandingkan dengan targepencapaian tujuan belajar, 3) Keberagaman mengandung makna bahwa dalam pendekatan ilmiah mengembangkan pendekatan keragaman. Pendekatan ini membawa konsekuensi siswa unik, kelompok siswa unik, termasuk keunikan dari kompetensi, materi, instruktur, pendekatan dan metode mengajar, serta konteks.

\section{Rumusan Masalah}

Dari latar belakang masalah yang di sebutkan di atas, maka rumusan masalah dalam penelitian ini adalah "Bagaimanakah Meningkatkatkan Prestasi Belajar IPS Materi Mengenal Perkembangan Tehnologi Transportasi Dengan Model CTL(Contextual Teaching and Learning) Siswa Kelas IV Semester II Sdn 2 Lekor Kecamatan Janapria Tahun Pelajaran 2016/2017"

\section{Tujuan Penelitian}

Sesuai dengan rumusan maslaah yang ada, penelitian ini bertujuan untuk mengetahui Bagaimana peningkatan Prestasi belajar siswa dalam pembelajaran Mengenal perkembangan teknologi transportas melalui pendekatan CTL (Contextual Teaching and Learning) di Kelas IV Semester II SDN 2 Lekor Kecamatan Janapria Tahun Pelajaran 2016/2017

\section{Manfaat Penelitian}

Manfaat penelitian ini adalah Memberikan bekal kecakapan berfikir ilmiah melalui keterlibatan siswa dalam kegiatan penelitian tindakan kelas yang dilakukan oleh guru dan Meningkatkan sikap profesional pendidik dan tenaga kependidikan.

\section{METODE PENELITIAN}

Adapun rancangan yang digunakan dalam penelitian ini adalah menggunakan Penelitian Tindakan Kelas (Classromm Activity Research). Pelaksanaan tindakan dalam PTK meliputi empat alur (langkah): (1) perencanaan tindakan; (2) pelaksanaan tindakan; (3) Pengamatan; refleksi.

Alur (langkah) pelaksanaan tindakan yang dimaksud dapat dilihat pada gambar berikut. Sebelum melaksanakan tindakan, terlebih dahulu peneliti merencanakan secara seksama jenis tindakan yang akan dilakukan. Kedua, setelah rencana disusun secara matang, barulah tindakan itu dilakukan. Ketiga, bersamaan dengan dilaksanakan tindakan, peneliti mengamati proses pelaksanaan tindakan itu sendiri dan akibat yang ditimbulkannya. Keempat, berdasarkan hasil pengamatan tersebut, peneliti kemudian melakukan refleksi atas tindakan yang telah dilakukan. Jika hasil refleksi menunjukkan perlunya dilakukan perbaikan atas tindakan yang telah dilakukan., maka rencana tindakan perlu disempurnakan lagi agar tindakan yang dilaksanakan berikutnya tidak sekedar mengulang apa yang telah diperbuat sebelumnya. Demikian 
seterusnya sampai masalah yang diteliti dapat mengalami kemajuan.

Adapun rancangan penelitian tindakan kelas ini dilakukan dalam II siklus. Dengan catatan: Apabila siklus I berhasil sesuai kriteria yang diinginkan, maka tetap dilakukan siklus II untuk pemantapan, tetapi kalau siklus I tidak berhasil, maka dilakukan siklus II dengan cara menyederhanakan materi dan menambah media pembelajaran. Apabila pada siklus II belum terjadi peningkatan, maka siklus II harus dipersiapkan untuk mengatasi kesulitan yang dialami siswa.

\section{HASIL PENELITIAN DAN PEMBAHASAN} HASIL PENELITIAN

Pra Siklus

Pada kegiatan observasi awal bertujuan untuk mengetahui kondisi semangat siswa mengikuti pelajaran Mengenal perkembangan Tehnologi Tramsportasi . Kemudian dari hasil tindakan pra siklus serta pengamatan langsung dalam kegiatan pembelajaran menunjukkan bahwa siswa belum mampu mengerjakan soal dengan benar dan menunjukkan sikap yang kurang semangat dalam belajar. Hal ini didukung pula dengan perolehan hasil belajar Mengenal perkembangan Tehnologi Tramsportasi pada kegiatan pra siklus yang belum mencapai standart KKM yang telah ditentukan oleh sekolah yaitu skor 70 untuk mata pelajaran IPS . Berdasarkan hasil dari kegiatan pra siklus diatas diperoleh kesimpulan bahwa pembelajaran yang bersifat konvensional dengan menggunakan ceramah dan pemberian tugas kurang mampu meningkatkan semangat siswa mengikuti pelajaran Mengenal perkembangan Tehnologi Tramsportasi .

\section{Siklus 1}

pada siklus ke I adalah meskipun masih terdapat beberapa kesulitan yang dihadapi oleh siswa dalam pembelajaran Mengenal perkembangan Tehnologi Tramsportasi , akan tetapi penerapan pendekatan CTL(Contextual Teaching and Learning) pada siklus I ini berjalan dengan cukup baik. Hal ini terlihat pada data hasil belajar Siswa dalam Mengikuti Pelajaran Mengenal perkembangan Tehnologi Tramsportasi pada siklus 1 yang rata-rata siswa sudah mencapai nilai KKM dan menunjukan adanya peningkatan nilai hasil belajar dari pra siklus.

\section{Siklus 2}

Penerapan pendekatan CTL(Contextual Teaching and Learning) banyak menuntut peran aktif siswa karena pendekatan ini adalah pendekatan pembelajaran yang berorientasi pada siswa. Hal ini dibuktikan dengan perolehan hasil belajar siswa yang mengalami peningkatan dimulai dari pelaksanaan pra siklus sampai pada siklus II. Hasil perolehan nilai siswa menunjukan adanya peningkatan nilai hasil belajar dari siklussiklus sebelumnya. Dapat di simpulkan bahwa ada peningkatan hasil belajar siswa dari pra siklus hingga siklus II. Terbukti bahwa jumlah siswa yang tuntas mengalami peningkatan, dan jumlah siswa yang belum tuntas mengalami penurunan.

"Semangat Siswa Mengikuti Pelajaran
$\begin{aligned} & \text { Mengenal perkembangan Tehnologi } \\ & \text { Tramsportasi " }\end{aligned}$
$\begin{array}{ll}\text { Satuan Pendidikan } & : \text { SDN } 2 \text { Lekor } \\ \text { Kelas/Semester } & : \text { VI } / 1 \\ \text { Mata Pelajaran } & : \text { IPS } \\ \text { Materi Pokok } & : \text { Mengenal } \\ \text { perkembangan Tehnologi Tramsportasi }\end{array}$

\begin{tabular}{|c|l|c|c|c|c|}
\hline No. & Aspek yang diobservasi & \multicolumn{3}{|c|}{ Pilihan } \\
\hline & & 1 & 2 & 3 & 4 \\
\hline 1 & Interaksi antar siswa dalam konteks pembelajaran. & & V & & \\
\hline 2 & Interaksi siswa dengan guru. & & V & & \\
\hline 3 & Kesungguhan dalam mengerjakan tugas kelompok. & & & V & \\
\hline 4 & Pembagiann tugas kellompok oleh siswa dengan baik & & V & & \\
\hline 5 & Pengelolaan kegiatan belajar oleh siswa. & & V & & \\
\hline 6 & Kerjasama yang baik antar siswa dalam belajar & & & V & \\
\hline 7 & Kemandirian siswa dalam belajar. & & & V & \\
\hline 8 & siswa menghargai pendanat orang lain. & & V & & \\
\hline 9 & siswa mengkritik orang lain dengan baik & & & V & \\
\hline 10 & siswa menghargai pendapat yang berbeda. & & & V & \\
\hline
\end{tabular}

Keterangan:
$1:$ Tidak ada
2: Jarang
3: Cukup banyak
4: Banyak

Tabel . Hasil Observasi Siklus 2"Semangat Siswa Mengikuti Pelajaran Mengenal perkembangan Tehnologi Tramsportasi "
Satuan Pendidikan
: SDN 2 Lekor
Kelas/Semester
: VI /2
Mata Pelajaran
: IPS
Materi Pokok
: Mengenal
perkembangan Tehnologi Tramsportasi

\begin{tabular}{|c|l|c|c|c|c|}
\hline \multirow{2}{*}{ No. Aspek yang diobservasi } & \multicolumn{3}{|c|}{ pilihan } \\
\hline & & 1 & 2 & 3 & 4 \\
\hline 1 & Interaksi antar siswa dalam konteks pembelajaran. & & & & $\mathrm{V}$ \\
\hline 2 & Interaksi siswa dengan guru. & & & & $\mathrm{V}$ \\
\hline 3 & Kesungguhan dalam mengerjakan tugas kelompok. & & & & $\mathrm{V}$ \\
\hline 4 & Pembagian tugas kelompok oleh siswa dengan baik & & & $\mathrm{V}$ & \\
\hline 5 & Pengelolaan kegiatan belajar oleh siswa. & & & $\mathrm{V}$ & \\
\hline 6 & Kerjasama yang baik antar siswa dalam belajar & & & & $\mathrm{V}$ \\
\hline 7 & Kemandirian siswa dalam belajar. & & & & $\mathrm{V}$ \\
\hline 8 & siswa menghargai pendapat orang lain. & & & & $\mathrm{V}$ \\
\hline 9 & siswa mengkritik orang lain dengan baik & & & & $\mathrm{V}$ \\
\hline 10 & siswa menghargai pendapat yang berbeda. & & & & $\mathrm{V}$ \\
\hline
\end{tabular}


Keterangan:
1 : Tidak ada
2: Jarang
3: Cukup banyak
4: Banyak

\section{PEMBAHASAN}

1. Pembahasan Siklus Pertama

Pada proses pelaksanaan siklus ke-1 siswa diminta untuk mempelajari Mengenal perkembangan Tehnologi Tramsportasi dalam IPS melalui pendekatan CTL(Contextual Teaching and Learning). Dengan pendekatan CTL(Contextual Teaching and Learning) yang berpusat pada siswa maka siswa lebih tertarik dan bersemangat dalam melaksanakan proses pembelajaran. Dengan pendekatan pembelajaran yang telah dilaksanakan maka terdapat peningkatan Semangat Siswa Mengikuti Pelajaran Mengenal perkembangan Tehnologi Tramsportasi. Terbukti pula dari data hasil belajar pada siklus 1 nilai rata rata yang siswa mencapai 72,1. Hasil observasi pada siklus 1 ini meskipun masih ada beberapa siswa yang tidak semnagat dalam pembelajaran. Tetapi pembelajaran pada siklus 1 ini berjalan lancar. Hal tersebut menunjukan adanya peningkatan Semangat Siswa Mengikuti Pelajaran Mengenal perkembangan Tehnologi Tramsportasi di bandingkan dengan pra siklus.

Pembahasan Siklus Kedua

Pada siklus ke II ini terdiri dari kegiatan perencanaan, pengamatan, dan refleksi tindakan.Pada siklus ini pelaksanaan pembelajaran dengan pendekatan CTL(Contextual Teaching and Learning) juga sama seperti yang di terapkan pada siklus I, dan hasil dari metode penelitian yang sudah di laksanakan menunjukkan peningkatan Semangat Siswa Mengikuti Pelajaran Mengenal perkembangan Tehnologi Tramsportasi . Hal tersebut dapat di lihat dari hasil rata rata nilai siswa yang pada siklus 2 ini mencapai 77,5. Dan pada hasil observasi sudah banyak siswa yang melakukan aktifitas dan kegiatan yang menunjukkan adanya semangat belajar dalam pembelajaran.

\section{SIMPULAN}

Kesimpulan dari penelitian ini adalah

1. Pada siklus 1 setelah menggunakan pendekatan CTL(Contextual Teaching and Learning) dalam pembelajaran maka terlihat adanya semangat siswa dalam mengikuti pelajaran Mengenal perkembangan Tehnologi Tramsportasi .

2. Pada siklus 1 setelah menggunakan pendekatan CTL(Contextual Teaching and
Learning) dalam pembelajaran maka terlihat peningkatan hasil belajar siswa dengan rata rata nilai siswa pada siklus 1 adalah 72,1 . Lebih besar dari pra siklus yang memperoleh rata rata hanya 66.3.

3. Pada siklus 2 setelah menggunakan pendekatan CTL(Contextual Teaching and Learning) dalam pembelajaran maka terlihat adanya peningkatan semangat siswa dalam mengikuti pelajaran Mengenal perkembangan Tehnologi Tramsportasi .

4. Pada siklus 2 setelah menggunakan pendekatan CTL(Contextual Teaching and Learning) dalam pembelajaran maka terlihat peningkatan hasil belajar siswa dengan rata rata nilai siswa pada siklus 2 adalah 77,5. Lebih besar dari pra siklus yang memperoleh rata rata hanya 66.3 , dan lebih besar dari siklus 1 yang memperoleh rata rata 72,1 .

5. Dapat di simpulkan bahwa penggunaan pendekatan CTL(Contextual Teaching and Learning) dalam meningkatkan semangat siswa mengikuti pelajaran Mengenal perkembangan Tehnologi Tramsportasi di Kelas IV Sekolah Dasar Negeri 2 Lekor Kecamatan Janapria Tahun Ajaran 2016/2017tepat sasaran.

\section{DAFTAR PUSTAKA}

Ahmadi, Abu dan Widodo Supriyono. 1991. Psikologi Belajar. Jakarta: Rineka Cipta.

Ahmad Rohani. (1997). Media Instruksional Edukatif. Jakarta: Rineka Cipta

Arief S. Sadiman, dkk. (2006). Media Pendidikan, Pengertian, Pengembangan, dan Pemanfaatannya. Jakarta: Pustekkom. Dikbud. dan PT. Raja Grafindo Persada

Darmansyah. 2006. Penelitian Tindakan Kelas. UNP

Depdiknas. 2004. Pedoman Penulisan Karya Ilmiah. Cetakan Eisi ke empat Malang Pers.

Goleman, Daniel, Emitional Intelligence Kecerdasan Emosional Mengapa EQ Lebih Penting Daripada IQ, Jakata: PT Gramedia Pustaka Utama, 2004.

Hamalik, Oemar. 2002. Proses Belajar Mengajar. Jakarta: Bumi Asara.

Ivor. K.Davies. 1991. Pengelolaan Belajar. Jakarta CV Rajawali

Nana Sujana. 1989. Teori-teori belajar Untuk pengajaran. Bandung

Ngalim Purwanto, Psikologi Pendidikan, Bandung: PT. Remaja Rosdakarya, 2002 
RosdaSardiman. 2006. Interaksi dan Prestasi Belajar Mengajar. Jakarta: Raja Grafindo Persada

Sugandi, Achmad. 2004. Teori Pembelajaran. Semarang: IKIP Semarang Press.

Slameto. 1995. Belajar Dan Faktor-Faktor Yang Mempengaruhi. Jakarta: Rineka Cipta. Sudjana, Nana. 2001. Penilaian Hasil Proses Belajar Mengajar. Bandung: Remaja Rosdakarya.

Syah, Muhibbin. 2006. Psikologi Belajar. Jakarta: PT Raja Grafindo Persada.

Tabrani Rusyan, Pendekatan dalam Proses Belajar Mengajar, Bandung: PT. Remaja Rosdakarya, 2001.

Tim Penyusun KBBI. 2007. Kamus Besar Bahasa Indonesia (edisi ketiga). Jakarta: Balai Pustaka.

Tim Penyusun Kamus Pembinaan dan Pengembangan Bahasa. (2005). Kamus Besar Bahasa Indonesia. Jakarta: Balai Pustaka

Wina Sanjaya. 2006. Strategi Pembelajaran. Jakarta. Kencana Wiradikromo Sartono. 2003. Dimensi Tiga. Jakarta. Erlangga

Zainal Abidin. 2004. Evaluasi Pengajaran. Padang. UNP 